\title{
Disintegration half-life of biodegradable plastic films on different marine beach sediments
}

\author{
Andreas Eich ${ }^{1}$, Miriam Weber $^{1}$, Christian Lott $^{\text {Corresp. } 1}$ \\ ${ }^{1}$ HYDRA Marine Sciences GmbH, Bühl, Germany \\ Corresponding Author: Christian Lott \\ Email address: c.lott@hydramarinesciences.com
}

The seafloor is considered the major sink for plastic debris in the world's oceans. Biodegradable polymers are available on the market as a substitute for conventional plastic and could potentially end up in the same environment. To gain more insight into the effects of different sediments on the degradation rate of biodegradable plastic we performed two iterative seawater tank experiments. First, to test the effect of sediment grain size, film of Mater-Bi HF03V, a blend of thermoplastic starch and biodegradable polyesters, was placed on the surface of mud as well as on four different grain size fractions of beach sand. Disintegration half-life was shortest on mud (139 days) and increased with the grain size of the beach sediment fractions (63 - $250 \mu \mathrm{m}$ : 296 days; 250 - $500 \mu \mathrm{m}$ : 310 days; 500 - $1000 \mu \mathrm{m}: 438$ days; > $1000 \mu \mathrm{m}: 428$ days). We assume that the higher surface-to-volume ratio in fine sediment compared to coarse sediment led to a higher bacterial abundance and thus to faster disintegration rates. In a follow-up experiment, the $<500 \mu \mathrm{m}$ fraction of sediment from four different beaches around Isola d'Elba, Italy, was used to test plastic disintegration as above. Additionally, polyhydroxybutyrate (PHB, MIREL P5001) was used as a positive control and high-density polyethylene (HD-PE) as a negative control. No disintegration was observed for HD-PE. Mater-Bi HF03V and PHB disintegrated significantly differently on sediment from different sites, with half-lives of Mater-Bi HF03V ranging from 72 to 368 days and of PHB from 112 to 215 days. Here, the half-life was shortest on slightly coarser sediment and at potentially anthropogenically impacted sites. We assume that the effect of the grain-size on the disintegration rate was masked by other parameters influencing the microbial community and activity. Understanding the parameters driving biodegradation is key to reliably report the range of disintegration rates occurring under the various conditions in different ecosystems. 


\title{
1 Disintegration half-life of biodegradable plastic films on
}

2 different marine beach sediments

3

4

5

\author{
Andreas Eich ${ }^{1}$, Miriam Weber ${ }^{1}$, Christian Lott $^{1}$ \\ ${ }^{1}$ HYDRA Marine Sciences GmbH, Bühl, Germany \\ Corresponding Author: \\ Christian Lott $^{1}$ \\ Steinfeldweg 15, 77815 Bühl Germany \\ Email address: c.lott@hydramarinesciences.com
}

\section{Abstract}

The seafloor is considered the major sink for plastic debris in the world's oceans. Biodegradable polymers are available on the market as a substitute for conventional plastic and could potentially end up in the same environment. To gain more insight into the effects of different sediments on the degradation rate of biodegradable plastic we performed two iterative seawater tank experiments.

First, to test the effect of sediment grain size, film of Mater-Bi HF03V, a blend of thermoplastic starch and biodegradable polyesters, was placed on the surface of mud as well as on four different grain size fractions of beach sand.

Disintegration half-life was shortest on mud (139 days) and increased with the grain size of the beach sediment fractions $(63-250 \mu \mathrm{m}: 296$ days; $250-500 \mu \mathrm{m}: 310$ days; $500-1000 \mu \mathrm{m}: 438$ days; $>1000 \mu \mathrm{m}: 428$ days). We assume that the higher surface-to-volume ratio in fine sediment compared to coarse sediment led to a higher bacterial abundance and thus to faster disintegration rates.

In a follow-up experiment, the $<500 \mu \mathrm{m}$ fraction of sediment from four different beaches around Isola d'Elba, Italy, was used to test plastic disintegration as above. Additionally, polyhydroxybutyrate (PHB, MIREL P5001) was used as a positive control and high-density polyethylene (HD-PE) as a negative control.

No disintegration was observed for HD-PE. Mater-Bi HF03V and PHB disintegrated significantly differently on sediment from different sites, with half-lives of Mater-Bi HF03V ranging from 72 to 368 days and of PHB from 112 to 215 days. Here, the half-life was shortest on slightly coarser sediment and at potentially anthropogenically impacted sites. We assume that the effect of the grain-size on the disintegration rate was masked by other parameters influencing the microbial community and activity. Understanding the parameters driving biodegradation is key to reliably report the range of disintegration rates occurring under the various conditions in different ecosystems. 


\section{Introduction}

41 Plastic pollution occurs in all ecosystems on the planet, including deep-sea trenches (Fischer et al., 2015), remote mountains (Allen et al., 2019), air (Dris et al., 2017), and the polar regions (Greenpeace, 2018; Peeken et al., 2018). Harmful effects of plastic waste in the environment are widely known (Li et al., 2016) and range from direct adverse impact on animals and plants (Derraik, 2002; Gregory, 2009; Guzzetti et al., 2018) to economic costs for society (Lee, 2015; McIlgorm et al., 2011). The substitution of conventional materials with biodegradable plastic, i.e. polymers and blends that degrade predominantly by the enzymatic action of microorganisms into $\mathrm{CO}_{2}$ (and in the absence of oxygen also $\mathrm{CH}_{4}$ ), water, inorganic compounds, and biomass (Albertsson et al., 2020), are discussed for certain applications. This can be a reasonable strategy in cases where plastics are made to remain in the environment (e.g. geotextiles), the potential of being lost is high (e.g. cigarette butts, agricultural mulch film, fish boxes), or the input into the environment is unavoidable (e.g. abrasion of tires, shoes, or textiles). As part of an assessment of potential environmental benefits and risks, the biodegradability of a material has to be proven before raising any claim thereof (Albertsson et al., 2020; Weber et al., 2018). Whether or not biodegradation takes place at all, and if so at which rate, not only depends on the chemical structure of the material but also on the conditions in the considered environment (Albertsson et al., 2020), which include temperature, $\mathrm{pH}$, humidity, oxygen availability, and the activity of microorganisms and their enzymes (Laycock et al., 2017). There is a variety of standard test methods available to assess biodegradability and biodegradation rates in different scenarios, simulating managed environments such as industrial and home compost or compartments of the open environment such as soil, freshwater, or the sea (Harrison et al., 2018). But even within one compartment, like the marine realm, conditions vary between different habitats, such as beaches, the water surface, the water column, the shallow-water seafloor and the deep sea, all of which also differ by climate zone (Lott et al. 2021). In laboratory tests, the biodegradability of a material can be proven by exposing the sample to marine microbial inocula under controlled conditions. Plastic samples are incubated in closed vessels, typically with a volume between 0.1 and $1 \mathrm{~L}$, and the metabolic end-products are analysed. This method has the advantage that plastic biodegradation can directly be quantified by measuring the evolved $\mathrm{CO}_{2}$ or the consumed $\mathrm{O}_{2}$ (Tosin et al. 2012; ISO 18830:2016, ISO 19679:2020). On the other hand, test conditions closer to real nature and applicable also to real products (e.g. bags, packaging) are achieved by exposing the plastic samples in-situ or in mesocosms (tanks) with a much higher volume than the laboratory flasks (Lott et al., 2020). In these open-system tests, the measurement of evolving $\mathrm{CO}_{2}$ is not possible, therefore plastic biodegradation cannot be directly quantified. Here, the disintegration of the sample can be measured as a proxy for the biodegradation of materials that have been proven to be biodegradable in closed-system laboratory tests, if the samples are well protected from physical impact. 
79 Most biodegradable polymers have a specific density higher than 1 and will sink in seawater

80 (e.g. 1.28 for Mater-Bi HF03V (Tosin et al., 2019), 1.30 for polyhydroxybutyrate MIREL P5001

81 and 1.20 for Kaneka PHBH, retrieved from www.matweb.com). Also materials with a lower

82 specific density or items containing lighter compartments such as bubbles or foam will

83 eventually sink due to fouling (Pauli et al., 2017). The marine seafloor is considered the major

84 sink for plastic debris in the world's ocean, with an estimated share of $94 \%$ of all marine plastic

85 accumulating (Eunomia, 2016). Plastic items sunken to the seafloor are initially in contact with

86 two matrices, seawater and sediment, until they are buried by sedimentation or biodegraded.

87 Most of the seafloor is covered with sediment. Depending on the hydrodynamic regime at a

88 given location the grain size ranges from blocks, stones, and gravel to sand and mud. Sediment

89

90

91

92

93

94

95

properties as e.g. permeability, oxygenation, and nutrient content directly or indirectly depend on the grain size, as do the microbial community and the biogeochemical processes linked to it (e.g. Ahmerkamp et al. 2020). This leads to the hypothesis that the biodegradation potential of sediment is influenced by its grain size. Albeit the importance as major plastic sink, studies on the degradation of plastic at the seafloor are scare and we are not aware of any study comparing the impact of different benthic conditions, e.g. sediment grain size, on degradation rates.

To gain more insight into the effects of different sediments on the degradation rate of biodegradable plastic we performed two iterative tank experiments. In a pilot study, marine sediment from one location was divided into four grain size fractions by sieving. The sediment fractions and mud were incubated with seawater in aquaria and the disintegration of the biodegradable plastic film Mater-Bi HF03V (Novamont, Italy) laying on the sediment surface was measured. In a follow-up experiment, sediment was collected from four different locations and directly put into aquaria. Here, plastic disintegration was tested the same way as above. Additionally, polyhydroxybutyrate (PHB) was used as a positive control and high-density polyethylene (HD-PE) as a negative control.

\section{Materials \& Methods}

106 Test materials

107 In both experiments, the degradation of Mater-Bi HF03V, a blend of thermoplastic starch and 108 biodegradable polyesters, was investigated (Tab. 1). In the pilot experiment, this material was still in an experimental phase and was tested as a film of $25 \mu \mathrm{m}$ thickness. In the follow-up study, the material was commercially available as fruit and vegetable bags of $12 \mu \mathrm{m}$ thickness.

111 The material (labelled ' $\mathrm{F} \& \mathrm{~V}$ Ecobag') was retrieved from a local supermarket and was produced

112 by Erreti S.r.l (Solbiate Olona, Italy) with Mater-Bi (Novamont, Italy). Mater-Bi HF03V is

113 certified as home compostable (OK compost HOME, Vinçotte S373, now TÜV Austria) and is

114 biodegradable in soil (Pischedda et al., 2019; Tosin et al., 2019). More information on the

115 specific material properties can be found in Pischedda et al., 2019 and Tosin et al., 2019.

116 In the second experiment, two additional materials were tested as controls (Tab. 1).

117 Polyhydroxybutyrate (PHB, MIREL P5001, Metabolix, Cambridge, USA), described by the

118 producer as 'PHA copolymer', is a polyester that is naturally produced by different 
119 microorganisms (Lu et al., 2009) and is biodegradable under marine conditions (Lott et al. 2021).

120 An FTIR analysis (Fig. SI-1) confirmed the material as PHB. Films of $85 \mu \mathrm{m}$ thickness were

121 used as a positive control to show that material disintegration is possible when using the selected

122 matrices. High-density polyethylene (HD-PE) fruit and vegetable bags with a thickness of $10 \mu \mathrm{m}$

123 were obtained from a local market (Marina di Campo, Italy). PE is the most widely used polymer

124 type for packaging and a conventional plastic that is regarded as not biodegradable. It was used

125 as a negative control to prove that no material disintegration occurred which is caused by

126 physical impact.

127

128

Experiments

129 Two experiments were performed in aquaria: To study the effect of sediment grain size on

130 material disintegration, the disintegration of the biodegradable plastic film laying on different

131 grain size fractions of beach sand, and additionally on mud, was tested in a pilot experiment. In a

132 follow-up experiment, three plastic materials were tested on natural sediments from four

133 different beaches.

134

135

Pilot experiment

136 Natural beach sand was collected at $0.1 \mathrm{~m}$ water depth at the beach of Fetovaia (Isola d'Elba,

137 Italy, Mediterranean Sea, 42 $44^{\prime} 00.1^{\prime \prime} \mathrm{N}, 010^{\circ} 09^{\prime} 15.3^{\prime \prime} \mathrm{E}$, Fig. 1), brought to the laboratory,

138 and wet sieved with natural seawater through standard sieves (Retsch, Germany) to the fractions

139 of $>1000 \mu \mathrm{m}, 1000-500 \mu \mathrm{m}, 500-250 \mu \mathrm{m}$, and $250-63 \mu \mathrm{m}$. Additionally, mud was taken

140 from the former saline basin at Terme S. Giovanni (Portoferraio, Isola d'Elba, 42 ${ }^{\circ} 48^{\prime} 12.1^{\prime \prime} \mathrm{N}$,

$\left.141010^{\circ} 19^{\prime} 01.0^{\prime \prime} \mathrm{E}\right)$ and used without further treatment. Five glass aquaria $(30 \mathrm{~cm}$ x $20 \mathrm{~cm} \times 20$

$142 \mathrm{~cm})$ were filled with a $6 \mathrm{~cm}$ thick layer of sediment $(3.6 \mathrm{~L})$ and a $10 \mathrm{~cm}$ thick layer of seawater

143 (6 L) collected at Seccheto (42 44' 06.5" N, 010 $10^{\circ} 33.5^{\prime \prime}$ E, Fig. 1). The tanks were closed

144 with plastic film to reduce evaporation. The water in each test tank was aerated and slightly

145 stirred by a bubbler connected to an air pump at ca. $37.5 \mathrm{~L} \mathrm{~h}^{-1}$ (SCHEGO, Germany). Aquaria

146 were kept in a climate chamber for ten months at $21^{\circ} \mathrm{C}$ (Fig. SI-2). Salinity was regularly

147 checked and kept at 39 with distilled water to compensate for evaporation loss. Salinity, oxygen

148 concentration, temperature, and $\mathrm{pH}$ were measured once every month with a conductivity sensor

149 TetraCon 925, an oxygen sensor FDO 925, and a pH sensor SenTix 940, attached to a Multi

1503420 (WTW, Weilheim, Germany).

151 Mater-Bi HF03V film was cut to the size of $20 \mathrm{~cm} \times 2 \mathrm{~cm}$. Five test strips were put between two

152 layers of plastic mesh (mesh width: $4 \mathrm{~mm} \mathrm{x} 4 \mathrm{~mm}$, diamond-shaped, polypropylene) to prevent

153 the potential loss of fragments and placed on the sediment surface of each test tank (Fig. 2, Fig.

154 SI-2). After 5 months (153 days), the samples were retrieved, carefully removed from the mesh,

155 and photographed (Canon 5D Mark II or Canon 600D with $50 \mathrm{~mm}$ macro lens) immersed in

156 seawater. Afterwards, the sample strips were re-arranged between the mesh and re-exposed in

157 the tanks. After 10 months (298 days), the sampling procedure was repeated and the experiment

158 terminated.

PeerJ reviewing PDF | (2021:03:59408:1:2:NEW 2 Jul 2021) 
159

160

161

162

163

164

165

166

167

168

169

170

171

172

173

174

175

176

177

178

179

180

181

182

183

184

185

186

187

188

189

190

191

192

193

194

195

196

197

198

\section{Follow-up experiment}

At four beaches around Isola d'Elba (Fig. 1), sediment was collected at $0.1 \mathrm{~m}$ water depth. In Fetovaia (same site as used for the pilot experiment), Marina di Campo (42 $44^{\prime} 36.13^{\prime \prime} \mathrm{N}, 10^{\circ}$

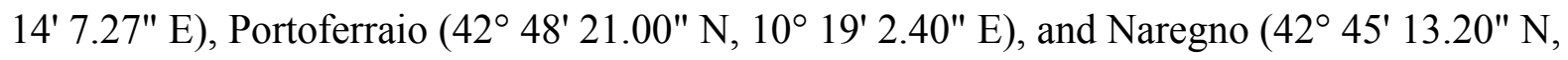
$10^{\circ} 24^{\prime} 19.80^{\prime \prime} \mathrm{E}$ ), sediment was sampled as described above and wet-sieved through a $500 \mu \mathrm{m}$ mesh to remove coarser particles and debris like shells, pebbles, and seagrass leaves.

Three glass aquaria $(30 \mathrm{~cm}$ x $20 \mathrm{~cm} \times 20 \mathrm{~cm})$ were filled with a layer of $4 \mathrm{~cm}(2.4 \mathrm{~L})$ of each of the four sediment types and $6 \mathrm{~L}$ of natural seawater collected in Seccheto (Fig. 1), which led to a replication of $\mathrm{n}=3$ for each sediment treatment. All 12 tanks were sealed with a lid made of plastic film with a small hole to allow the passage of an air hose (Fig. SI-4).

The salinity was regularly checked as described above and if necessary adjusted to 39 with distilled water. Dissolved oxygen was around $95 \%$ air saturation and pH around 8.1 (Fig. SI-5). In contrast to the pilot experiment, the aquaria were not kept in a climate chamber, but the temperature was allowed to change with the seasons. The water temperature was monitored with loggers (UA-002-64, Onset Computer Corporation, Bourne, USA) and ranged from 12 to $29{ }^{\circ} \mathrm{C}$ (Fig. SI-6). Samples from the four sediment types and natural seawater used for the experiments were sent to an external laboratory for grain size analysis (CSA, Rimini, Italy) and basic geochemical characterization (Limnowak, Ottersberg, Germany). The grain size distributions were analysed using GRADISTAT V8 (Blott \& Pye, 2001). The organic matter, calciumcarbonate, and silicate contents were calculated using the loss-on-ignition method (Heiri et al., 2001).

Test materials were cut to strips of $6 \times 8 \mathrm{~cm}$. Each specimen was put between two layers of polyester mesh (SEFAR, Heiden, Switzerland) with a square-shaped mesh of $2 \times 2 \mathrm{~mm}$ and held together at the short sides with plastic clamps. One replicate of each material was randomly placed in each aquarium.

After the start of the experiment, sampling occurred after 129, 186, and 252 days for the experiments with Marina di Campo, Portoferraio, and Naregno sediment. The last sampling for the test with Fetovaia sediment was after 356 days because after 252 days, the disintegrated area of Mater-Bi HF03V in the Fetovaia treatment was estimated to be below $50 \%$ and much lower than in the other treatments. During sampling, one replicate of each material was retrieved from each of the three aquaria containing the same type of sediment. The upper mesh was carefully removed. Depending on the state of disintegration, the samples were photographed with or without the lower mesh. No re-exposure of the specimens occurred.

\section{Determination of disintegration}

Disintegration was determined photogrammetrically as described before (Lott et al., 2020). The remaining plastic was marked on the photos and the area loss of the total exposed area was measured using ImageJ (Abramoff et al., 2004). 
199

200

201

202

203

204

205

206

207

208

209

210

211

212

213

214

215

216

217

218

219

220

221

222

223

224

225

226

227

228

229

230

231

232

233

234

235

236

237

238

\section{Statistical Analysis - Calculation of half-life}

All data was analysed in R (R Core Team, 2020) as described in Lott et al. (2021). The disintegration over time was modelled using beta regression (betareg package) and the appropriate link-function (logit, cloglog, cauchit, or loglog) selected by comparing the Root Mean Square Deviation (package $c a r e t$ ). Half-life was calculated by back-transforming linkfunctions for $50 \%$ material disintegration and solving the formula for the time $\left(t_{0.5}\right)$ using the coefficients estimated by the linear model. Monte-Carlo simulations were used to calculate 500,0000 half-live values considering the variance of the model coefficients, which allowed statistical tests with empirical $p$-values.

\section{Results}

\section{Pilot experiment}

The test material Mater-Bi HF03V showed substantial disintegration on mud after 153 days and on all grain-size fractions within 298 days (Fig. 2).

The half-life differed significantly between different sediment size fractions and was lowest for samples on mud (139 days), followed by samples on the sediment with a size fraction of $63-250$ $\mu \mathrm{m}$ (296 days), 250 - $500 \mu \mathrm{m}$ (310 days), and sediment above $500 \mu \mathrm{m}$ (Fig. 3 and 4, Tab. SI-1 and SI-2). Throughout the experiment, the monitored environmental conditions (dissolved oxygen concentration, temperature, $\mathrm{pH}$, and salinity) varied little (Fig. SI-3).

\section{Follow-up experiment}

Disintegration was obvious for the biodegradable materials Mater-Bi HF03V and PHB (Fig. 5, Fig. SI-7). HD-PE did not disintegrate within 356 days.

The predicted half-life for Mater-Bi HF03V ranged from 72 to 368 days and for PHB from 112 to 259 days (Fig. 6, Tab. SI-4). PHB disintegrated significantly faster on Marina di Campo sediment than on all other sediment types. Also for Mater-Bi HF03V, the disintegration on Marina di Campo sediment and on Portoferraio sediment was significantly faster than on Naregno sediment (Tab. SI-5 and SI-6). The observed disintegration of Mater-Bi HF03V on Fetovaia sediment and of PHB on Naregno sediment was variable at the last sampling point (Mater-Bi HF03V after 356d: 0, 54.8, and 97.8 \% area loss; PHB after $252 \mathrm{~d}: 7.1,50.3$, and 88.3 $\%$ area loss).

All sediment types consisted almost completely of silicate (97-98\%, Tab. 2). According to the Folk \& Ward method (1957), the sediment collected in Marina di Campo was medium sand, all other sediments were fine sand. All sediment types were well or very well sorted (Fig. 7, Tab. 2). Portoferraio sediment had a higher phosphorous content (190 $\mathrm{mg} \mathrm{kg}^{-1}$ dry weight) than the other sediments (80 - $110 \mathrm{mg} \mathrm{kg}^{-1}$ dry weight, Tab. 2). No statistical tests could be performed as the analysis was done for only one sample per site. In the water phase of the aquaria, environmental conditions such as salinity, $\mathrm{pH}$, and oxygen saturation varied little throughout the experiment (Fig. SI-5). The concentration of nitrate was $0.14 \mathrm{mg} \mathrm{L}^{-1}$, of ortho-phosphate $0.008 \mathrm{mg} \mathrm{L}^{-1}$, and of ammonia $0.13 \mathrm{mg} \mathrm{L}^{-1}$ (Tab. SI-3). 


\section{Discussion}

241 In the pilot experiment, it was shown that the disintegration rate of biodegradable plastic film on marine sediment is affected by grain size. Disintegration time was shortest on mud, followed by samples laying on the smallest grain size fraction and significantly increased with increasing grain size of the sieved sand (Fig. 4, Tab. SI-1 and SI-2). The biodegradation rate of organic substances depends on the activity and abundance of microorganisms. Both are influenced by environmental conditions such as temperature, $\mathrm{pH}$, salinity, and oxygen concentration. Sediment characteristics, like grain size, porosity, and permeability influence these conditions (Ahmerkamp et al., 2020; Probandt et al., 2017). Permeability increases with grain size. High permeability is usually connected with low bacterial biomass (Hou et al., 2017) and thus, hypothetically, with a lower biodegradation rate. However, if plastic samples are laying on the sediment surface, the permeability of the underlaying matrix may only play a minor role. Most benthic bacteria live attached to sediment grains (Probandt et al., 2018), therefore the available space, i.e. surface area of grains, is important. For small grains, the surface-to-volume ratio is higher than for larger grains. This implies a larger surface area available for microbial colonisation and thus a negative relationship between grain size and bacterial abundance (Rublee \& Dornseif, 1978). Furthermore, during the sieving process, fine organic-rich compounds might have been washed out from the bulk sediment into the finer fractions, which would increase bacterial abundance and activity (Cammen, 1982; Rublee, 1982; Stoeck \& Albers, 1999). These observations for manipulated sediment led to a follow-up experiment in which the influence of natural beach sediment, containing a mix of different grain sizes, on the disintegration of biodegradable plastic was assessed. Here, additionally to Mater-Bi HF03V, a positive (PHB) and negative control (HD-PE) was tested. Overall, the half-life of PHB (112 to 259 days) was in a similar range as in a previous study with similar settings. Lott et al. (2021) tested the same PHB material on Mediterranean benthic calcareous sediment in laboratory, mesocosm, and field experiments. The predicted half-live was 116 days in the laboratory experiment (at constantly $20^{\circ} \mathrm{C}$ ), 357 days in the mesocosm experiment (at constantly $20.5^{\circ} \mathrm{C}$ ), and 654 days in the field experiment (at $14-20^{\circ} \mathrm{C}$ ). The predicted half-life in an additional field experiment on calcareous sediment in tropical SE Asia (at a mean temperature of $28.6^{\circ} \mathrm{C}$ ) was 54 days. This confirms the test conditions applied here as environmentally relevant.

271 The disintegration of a not further specified type of Mater-Bi was tested in a benthic field experiment off Isola d'Elba at a depth of $36 \mathrm{~m}$ (Pauli et al., 2017). Disintegration after one year was lower (mean $13 \%$, all replicates below $30 \%$ ) and less variable than in this study. The temperature in our study was probably more stable than in the field test with positive effects on biodegradation rates. No other studies investigated the degradation of Mater-Bi HF03V under marine conditions. However, based on laboratory tests investigating the effect of temperature on the biodegradation rates in soil, formulas are given to calculate the theoretical biodegradation time needed under different temperatures for samples with a given surface area and weight. 
279 These formulas can be adapted to calculate the theoretical half-life of samples with the 280 dimension used in this study. For the pilot experiment, the theoretical half-life is 28 days at 20

$281{ }^{\circ} \mathrm{C}$ and for the follow-up experiment, using thinner films, 13 days. Mater-Bi HF03V exposed to

282 soil seems to degrade much faster than exposed to the marine sediments used in this study with a

283 minimal half-life of 153 days in the pilot experiment and 72 days. Also, other studies observed

284 lower biodegradation rates under marine conditions compared to terrestrial settings (Chamas et

285 al., 2020).

286 PHB disintegrated significantly faster on Marina di Campo sediment than on the other sediment

287 types. Also, Mater-Bi HF03V disintegrated fastest on Marina di Campo sediment, but similarly

288 fast on Portoferraio sediment. Different than expected from the results of the pilot study, the

289 disintegration was faster for the coarser Marina di Campo sediment. The grain size

290 characteristics of the Portoferraio sediment was not substantially different from those of Naregno

291 and Fetovaia sediment (Fig. 6, Tab. SI-4 to SI-6). This implies that other environmental factors

292 were crucial and masked the effect of the grain size. For instance, the organic matter content has

293 a strong positive impact on the bacterial abundance (Cammen, 1982; Rublee, 1982; Stoeck \&

294 Albers, 1999). However, the organic carbon content in all sediment types was below the

295 detection limit of $0.1 \%$ dry mass. Also, when applying the loss-on-ignition method, similar

296 values were calculated for the organic matter content in all sediments $(0.6-1.1 \%)$. No statistical

297 tests could be performed due to the lack of replication. The phosphorous content in the

298 Portoferraio sediment was slightly higher than in the other sediment types. Phosphorous

299 concentrations from all sites were low compared to a study in the Mediterranean Sea in Turkey

300 (Gunduz et al., 2011). The relatively higher concentration of phosphorous in sediment from

301 Portoferraio, the largest town on the island, probably resulted from sewage or industrial effluents

302 (Berthold et al., 2018; Howell, 2010). Also, Marina di Campo is a small town with more

303 inhabitants than the villages Fetovaia and Naregno, therefore an anthropogenic impact on the

304 bacterial abundance or activity is probable and could explain the faster disintegration. A

305 microbial community presumably exposed to a wider range of organic substances e.g. in

306 municipal waste waters from Marina di Campo and Portoferraio may be more prepared or pre-

307 adapted for the degradation of a more complex blend than the community on beaches low in

308 anthropogenic organics input. A more in-depth study, comparing the composition and metabolic

309 functionality of each of the beach sediments could help to explain the differences in the

310 biologically driven disintegration of biodegradable plastic materials observed in this study.

311 The disintegration of Mater-Bi HF03V on Fetovaia sediment and PHA on Nargeno sediment was

312 highly variable. This could be caused by processes occurring during material disintegration. The

313 increasing biodegradation weakens the structure of the film until reaching an unstable

314 equilibrium. Then, even small differences in biodegradation rates have strong effects on the

315 physical integrity of the sample and therefore its disintegration.

316

317 Conclusions 
318 From the pilot experiment, we conclude that in general there is a strong impact of sediment

319 characteristics on the disintegration rate. In natural beach sediment containing a mix of different

320

321

322

323

324

325

326

327

328

329

330

331

332

333

334

335

336

337

338

339

340

341

342

343

344

345

346

347

348

349

350

351

352

353

354

355

356

357 grain sizes, no such clear effects could be observed and differences in material disintegration could be masked by additional environmental parameters. The impact of anthropogenically influenced sediment on the biodegradation rates of biodegradable polymers should be further investigated.

\section{Acknowledgements}

We thank D. Makarow and B. Unger for technical help with the experiments.

\section{References}

Abramoff, M. D., Magalhaes, P. J., \& Ram, S. J. (2004). Image Processing with ImageJ. Biophotonics International, 11(7), 36-42.

Ahmerkamp, S., Marchant, H. K., Peng, C., Probandt, D., Littmann, S., Kuypers, M. M. M., \& Holtappels, M. (2020). The effect of sediment grain properties and porewater flow on microbial abundance and respiration in permeable sediments. Scientific Reports, 10(1), 1-12. https://doi.org/10.1038/s41598-020-60557-7

Albertsson, A., Bødtker, G., Boldizar, A., Filatova, T., Prieto Jimenez, M., Loos, K., Poortinga, W., Sander, M., Seppälä, J., Thompson, R., \& Weber, M. (2020). Biodegradability of plastics in the open environment. Science Advice for Policy by European Academies, Evidence Review Report no. 8. https://doi.org/10.26356/biodegradabilityplastics

Allen, S., Allen, D., Phoenix, V. R., Le Roux, G., Durántez Jiménez, P., Simonneau, A., Binet, S., \& Galop, D. (2019). Atmospheric transport and deposition of microplastics in a remote mountain catchment. Nature Geoscience, 12(5), 339-344. https://doi.org/10.1038/s41561-0190335-5

Berthold, M., Zimmer, D., Reiff, V., \& Schumann, R. (2018). Phosphorus contents re-visited after 40 years in muddy and sandy sediments of a temperate lagoon system. Frontiers in Marine Science, 5, 305. https://doi.org/10.3389/fmars.2018.00305

Blott, S. J., \& Pye, K. (2001). Gradistat: A grain size distribution and statistics package for the analysis of unconsolidated sediments. Earth Surface Processes and Landforms, 26(11), 12371248. https://doi.org/10.1002/esp.261

Cammen, L. M. (1982). Effect of particle size on organic content and microbial abundance within four marine sediments. Marine Ecology Progress Series, 9, 273-280.

Chamas, A., Moon, H., Zheng, J., Qiu, Y., Tabassum, T., Jang, J. H., Abu-Omar, M., Scott, S. L. and Suh, S. (2020). Degradation rates of plastics in the environment. ACS Sustainable Chemistry \& Engineering, 8(9), 3494-3511. https://doi.org/10.1021/acssuschemeng.9b06635

Derraik, J. G. B. (2002). The pollution of the marine environment by plastic debris: a review. Marine Pollution Bulletin, 44(9), 842-852. https://doi.org/10.1016/S0025-326X(02)00220-5 Dris, R., Gasperi, J., Mirande, C., Mandin, C., Guerrouache, M., Langlois, V., \& Tassin, B. (2017). A first overview of textile fibers, including microplastics, in indoor and outdoor 
358

359

360

361

362

363

364

365

366

367

368

369

370

371

372

373

374

375

376

377

378

379

380

381

382

383

384

385

386

387

388

389

390

391

392

393

394

395

396

environments. Environmental Pollution, 221, 453-458.

https://doi.org/10.1016/j.envpol.2016.12.013

Eunomia. (2016). Plastics in the Marine Environment. https://www.eunomia.co.uk/reportstools/plastics-in-the-marine-environment/

Fischer, V., Elsner, N. O., Brenke, N., Schwabe, E., \& Brandt, A. (2015). Plastic pollution of the Kuril-Kamchatka Trench area (NW Pacific). Deep-Sea Research Part II: Topical Studies in Oceanography, 111, 399-405. https://doi.org/10.1016/j.dsr2.2014.08.012

Folk, R. L., \& Ward, W. (1957). A Study in the Significance of Grain-Size Parameters. Journal of Sedimentary Petrology, 27(3-26). https://doi.org/10.1306/74D70646-2B21-11D7$8648000102 \mathrm{C} 1865 \mathrm{D}$

Greenpeace. (2018). Microplastics and persistent fluorinated chemicals in the Antarctic. https://storage.googleapis.com/p4-production-content/international/wpcontent/uploads/2018/06/4f99ea57-microplastic-antarctic-report-final.pdf Gregory, M. R. (2009). Environmental implications of plastic debris in marine settingsentanglement, ingestion, smothering, hangers-on, hitch-hiking and alien invasions. Philosophical Transactions of the Royal Society of London. Series B, 364, 2013-2025.

https://doi.org/10.1098/rstb.2008.0265

Gunduz, B., Aydin, F., Aydin, I., \& Hamamci, C. (2011). Study of phosphorus distribution in coastal surface sediment by sequential extraction procedure (NE Mediterranean Sea, AntalyaTurkey). Microchemical Journal, 98(1), 72-76. https://doi.org/10.1016/j.microc.2010.11.006 Guzzetti, E., Sureda, A., Tejada, S., \& Faggio, C. (2018). Microplastic in marine organism: Environmental and toxicological effects. Environmental Toxicology and Pharmacology, 64, 164-171. https://doi.org/10.1016/j.etap.2018.10.009

Harrison, J. P., Boardman, C., Callaghan, O., Delort, A., \& Song, J. (2018). Biodegradability standards for carrier bags and plastic films in aquatic environments : a critical review. Royal Society Open Science, 5(171792). https://doi.org/10.1098/rsos.171792 Heiri, O., Lotter, A. F., \& Lemcke, G. (2001). Loss on ignition as a method for estimating organic and carbonate content in sediments: Reproducibility and comparability of results. Journal of Paleolimnology, 25(1), 101-110. https://doi.org/10.1023/A:1008119611481 Hou, Z., Nelson, W. C., Stegen, J. C., Murray, C. J., Arntzen, E., Crump, A. R., Kennedy, D. W., Perkins, M. C., Scheibe, T. D., Fredrickson, J. K., \& Zachara, J. M. (2017). Geochemical and Microbial Community Attributes in Relation to Hyporheic Zone Geological Facies. Scientific Reports, 7(1), 1-17. https://doi.org/10.1038/s41598-017-12275-w

Howell, J. A. (2010). The distribution of phosphorus in sediment and water downstream from a sewage treatment works. Bioscience Horizons, 3(2), 113-123. https://doi.org/10.1093/biohorizons/hzq015 International Organization for Standardization. (2016). ISO 18830:2016 Plastics - Determination of aerobic biodegradation of non-floating plastic materials in a seawater/sandy sediment interface - Method by measuring the oxygen demand in closed respirometer. 
397 International Organization for Standardization. (2020). ISO 19679:2020 Plastics - Determination

398 of aerobic biodegradation of non-floating plastic materials in a seawater/sediment interface -

399 Method by analysis of evolved carbondioxide.

400 Laycock, B., Nikolić, M., Colwell, J. M., Gauthier, E., Halley, P., Bottle, S., \& George, G.

401 (2017). Lifetime prediction of biodegradable polymers. Progress in Polymer Science, 71, 144

402 189. https://doi.org/10.1016/j.progpolymsci.2017.02.004

403 Lee, J. (2015). Economic valuation of marine litter and microplastic pollution in the marine

404 environment: An initial assessment of the case of the United Kingdom. Discussion Paper,

405 March, 1-16.

406 Li, W. C., Tse, H. F., \& Fok, L. (2016). Plastic waste in the marine environment: A review of

407 sources, occurrence and effects. Science of the Total Environment, 566-567, 333-349.

408 https://doi.org/10.1016/j.scitotenv.2016.05.084

409 Lott, C., Eich, A., Makarow, D., Unger, B., Eekert, M. Van, Schuman, E., Reinach, M. S., Lasut,

410 M. T., \& Weber, M. (2021). Half-life of biodegradable plastics in the marine environment

411 depends on material, habitat, and climate zone. Frontiers in Marine Science, 8, 426.

412 https://doi.org/10.3389/fmars.2021.662074

413 Lott, C., Eich, A., Unger, B., Makarow, D., Battagliarin, G., Schlegel, K., Lasut, M. T., \&

414 Weber, M. (2020). Field and mesocosm methods to test biodegradable plastic film under marine

415 conditions. PLoS ONE, 15(7 July), 1-26. https://doi.org/10.1371/journal.pone.0236579

416 Lu, J., Tappel, R. C. T., \& Nomura, C. T. (2009). Mini-Review : Biosynthesis of

417 Poly(hydroxyalkanoates). Journal of Macromolecular Science, 49, 226-248.

418 https://doi.org/10.1080/15583720903048243

419 McIlgorm, A., Campbell, H. F., \& Rule, M. J. (2011). The economic cost and control of marine

420 debris damage in the Asia-Pacific region. Ocean and Coastal Management, 54(9), 643-651.

421 https://doi.org/10.1016/j.ocecoaman.2011.05.007

422 Pauli, N. C., Petermann, J. S., Lott, C., \& Weber, M. (2017). Macrofouling communities and the

423 degradation of plastic bags in the sea: An in situ experiment. Royal Society Open Science, 4(10).

424 https://doi.org/10.1098/rsos.170549

425 Peeken, I., Primpke, S., Beyer, B., Gütermann, J., Katlein, C., Krumpen, T., Bergmann, M.,

426 Hehemann, L., \& Gerdts, G. (2018). Arctic sea ice is an important temporal sink and means of

427 transport for microplastic. Nature Communications, 9(1). https://doi.org/10.1038/s41467-018-

$428 \quad 03825-5$

429 Pischedda, A., Tosin, M., \& Degli-Innocenti, F. (2019). Biodegradation of plastics in soil: The

430 effect of temperature. Polymer Degradation and Stability, 170(109017).

431 https://doi.org/10.1016/j.polymdegradstab.2019.109017

432 Probandt, D., Eickhorst, T., Ellrott, A., Amann, R., \& Knittel, K. (2018). Microbial life on a sand 433 grain: From bulk sediment to single grains. ISME Journal, 12(2), 623-633.

434 https://doi.org/10.1038/ismej.2017.197

435 Probandt, D., Knittel, K., Tegetmeyer, H. E., Ahmerkamp, S., Holtappels, M., \& Amann, R.

436 (2017). Permeability shapes bacterial communities in sublittoral surface sediments.

PeerJ reviewing PDF | (2021:03:59408:1:2:NEW 2 Jul 2021) 
437 Environmental Microbiology, 19(4), 1584-1599. https://doi.org/doi.org/10.1111/1462-

$438 \quad 2920.13676$

439 R Core Team. (2020). R: A Language and Environment for Statistical Computing. R Foundation 440 for Statistical Computing.

441 Rublee, P. A. (1982). Bacteria and Microbial Distribution in Estuarine Sediments. Estuarine

442 Comparisons - Proceedings of the Sixth Biennial International Estuarine Research Conference, 443 Gleneden Beach, Oregon, November 1-6, 1981, 159-182.

444 Rublee, P. A., \& Dornseif, B. E. (1978). Direct Counts of Bacteria in the Sediments of a North 445 Carolina Salt Marsh. Estuaries, 1(3). https://doi.org/10.2307/1351462

446 Stoeck, T., \& Albers, B. P. (1999). Benthic microbial biomass and activity in marine sediments 447 with TOC gradient. Senckenbergiana Maritima, 29, 145-147.

448 https://doi.org/10.1007/bf03043141

449 Tosin, M., Pischedda, A., \& Degli-Innocenti, F. (2019). Biodegradation kinetics in soil of a 450 multi-constituent biodegradable plastic. Polymer Degradation and Stability, 166, 213-218.

451 https://doi.org/10.1016/j.polymdegradstab.2019.05.034

452 Tosin, M., Weber, M., Siotto, M., Lott, C., \& Degli Innocenti, F. (2012). Laboratory test 453 methods to determine the degradation of plastics in marine environmental conditions. Frontiers 454 in Microbiology, 3, 1-9. https://doi.org/10.3389/fmicb.2012.00225

455 Weber, M., Unger, B., Mortier, N., Wilde, B. De, Eekert, M. Van, Schuman, E., Tosin, M., 456 Pognani, M., Innocenti, F. D., \& Briassolis, D. (2018). Assessing Marine Biodegradability of 457 Plastic - Towards an Environmentally Relevant International Standard Test Scheme.

458 Proceedings of the International Conference on Microplastic Pollution in the Mediterranean

459 Sea, 189-193. https://doi.org/10.1007/978-3-319-71279-6 
Figure 1

Sampling sites around the Island of Elba, Italy.

Pilot experiment: Beach sediment was collected in Fetovaia and mud in Portoferraio. Followup experiment: Sediment was collected in Fetovaia, Marina di Campo, Portoferraio and Naregno. Seawater for both experiments was collected in Seccheto (yellow dot). ( ) OpenStreetMap contributors.

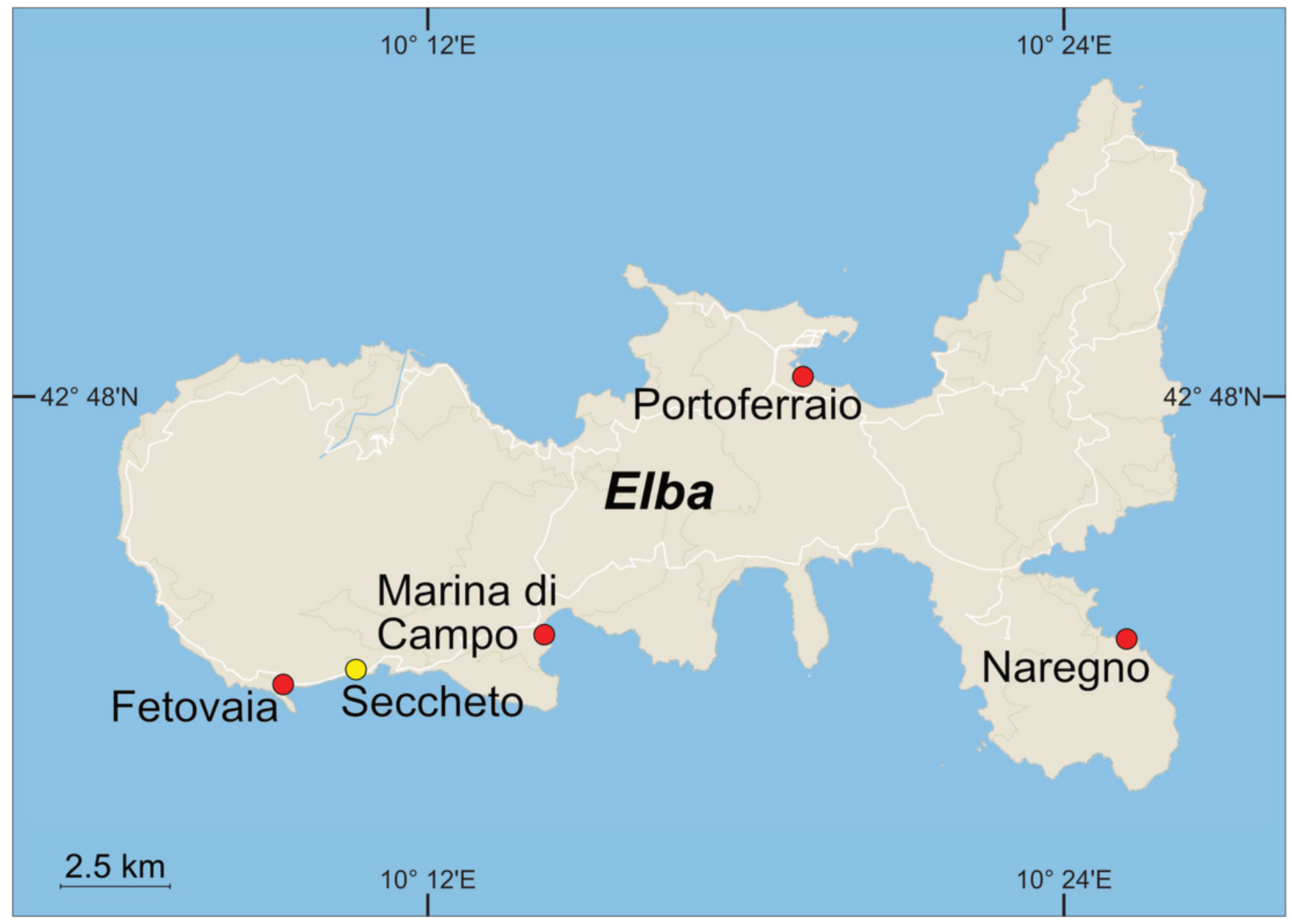




\section{Figure 2}

Samples of Mater-Bi HF03V.

Sample strips were placed at the sediment surface of the grain size fractions $>1000 \mu \mathrm{m}, 500$ - $1000 \mu \mathrm{m}, 250-500 \mu \mathrm{m}, 63-250 \mu \mathrm{m}$, and mud (columns) and photographed after 153 and 298 days (rows).

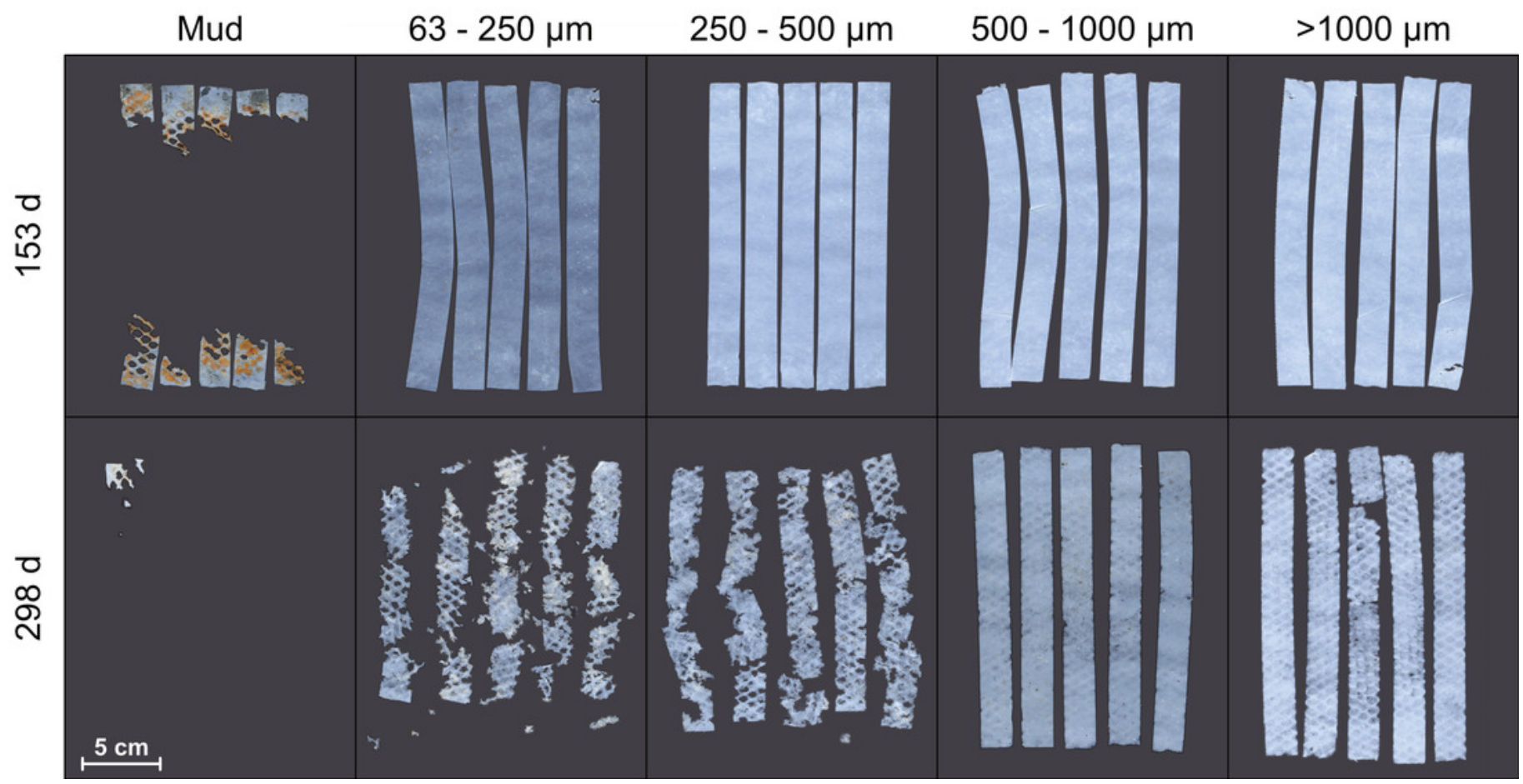


Figure 3

\section{Disintegration of Mater-Bi HF03V.}

Film $(25 \mu \mathrm{m})$ was exposed on different grain size fractions of the same sediment and mud. Model curve and $95 \%$ confidence interval (shaded area).

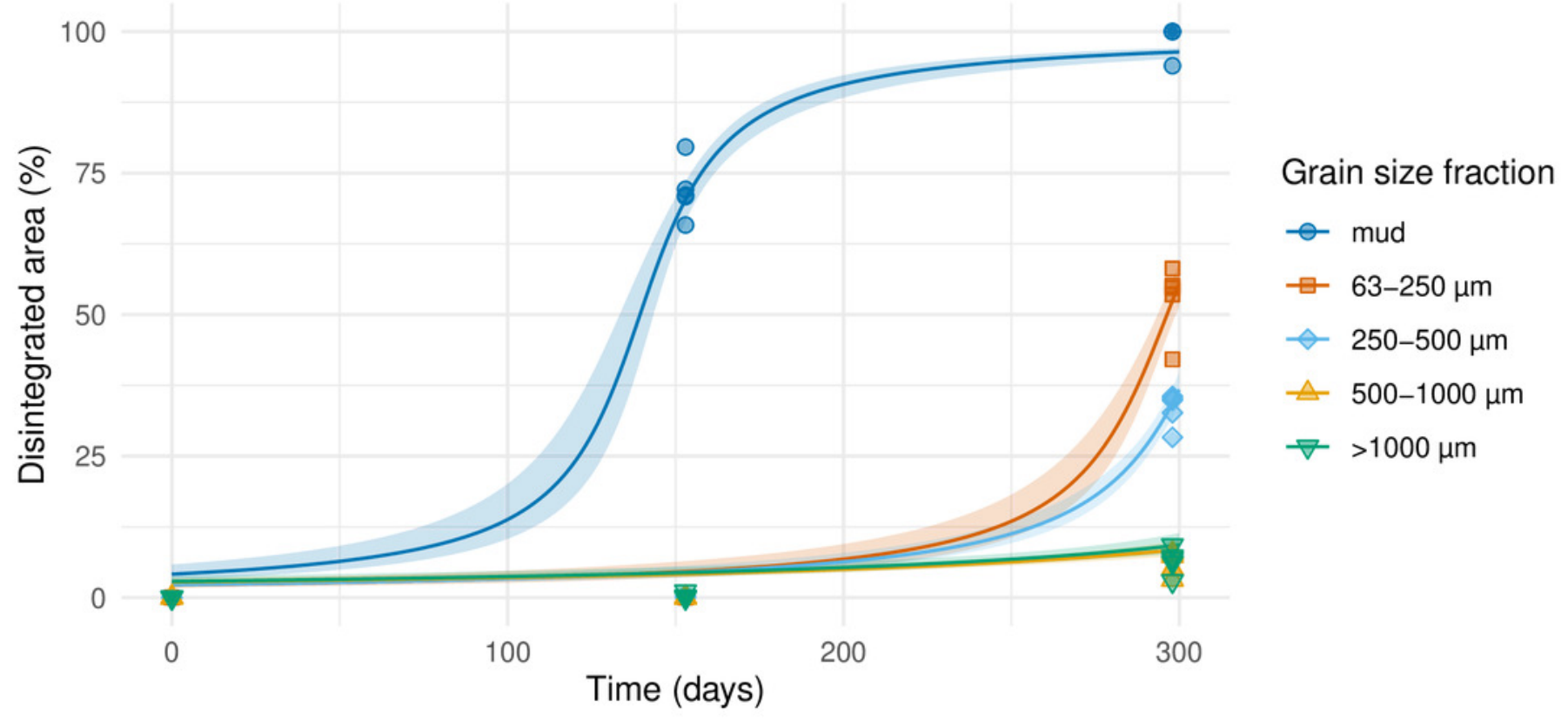


Figure 4

Predicted half-life of Mater-Bi HF03V film ( $25 \mu \mathrm{m})$ on different grain size fractions of the same sediment and mud.

The distributions of the $95 \%$ confidence intervals of 500,000 calculated half-life values are shown as violin plots. Significantly different half-life values (empirical $p$-values) have different letters above the plots. The number below the point is the predicted half-life.

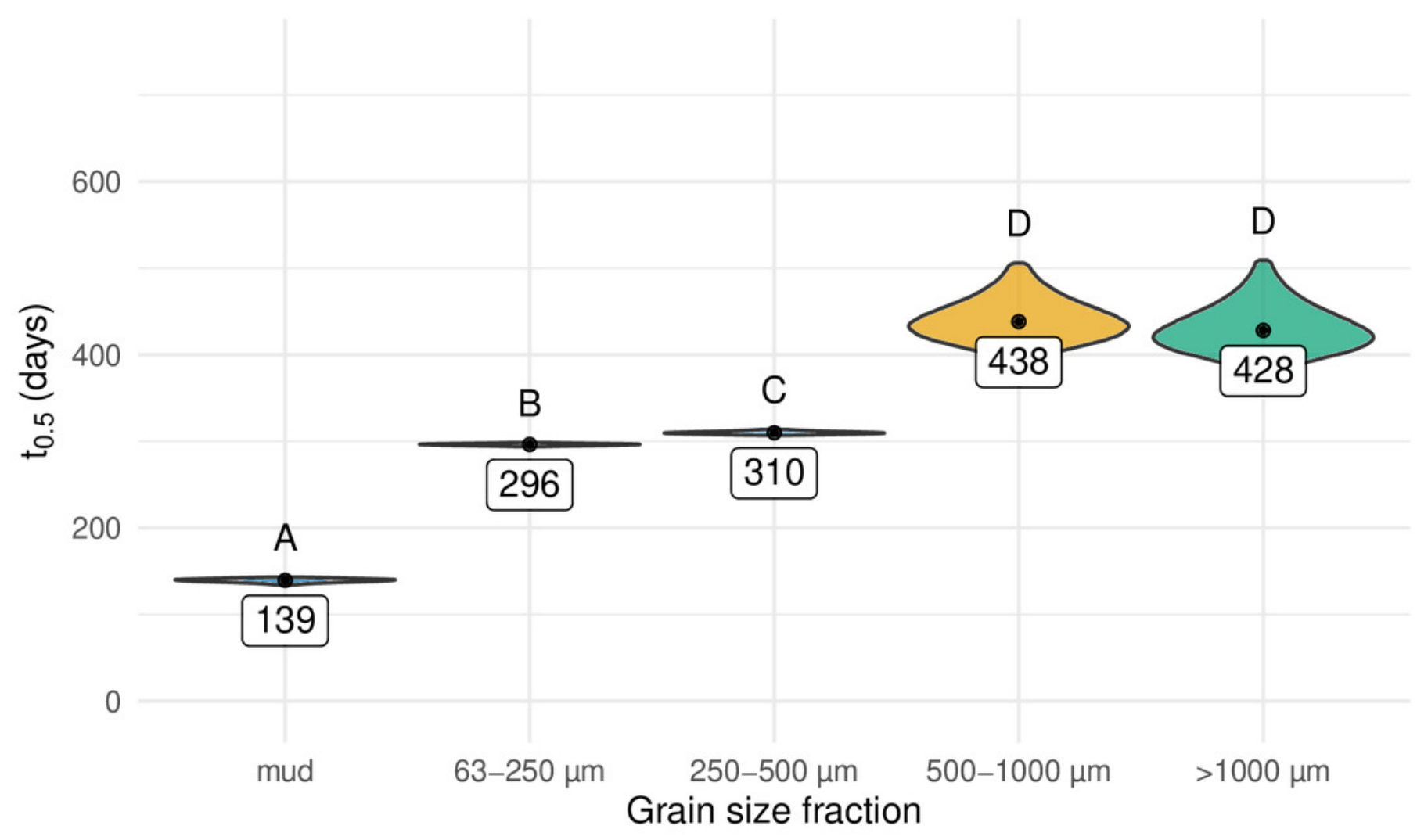


Figure 5

A) Disintegration of Mater-Bi HF03V film (12 $\mu \mathrm{m})$ and B) PHB $(85 \mu \mathrm{m})$ on sediments from four different beaches.

Model curve and $95 \%$ confidence interval (shaded area). 
A)

\section{Mater-Bi HF03V}

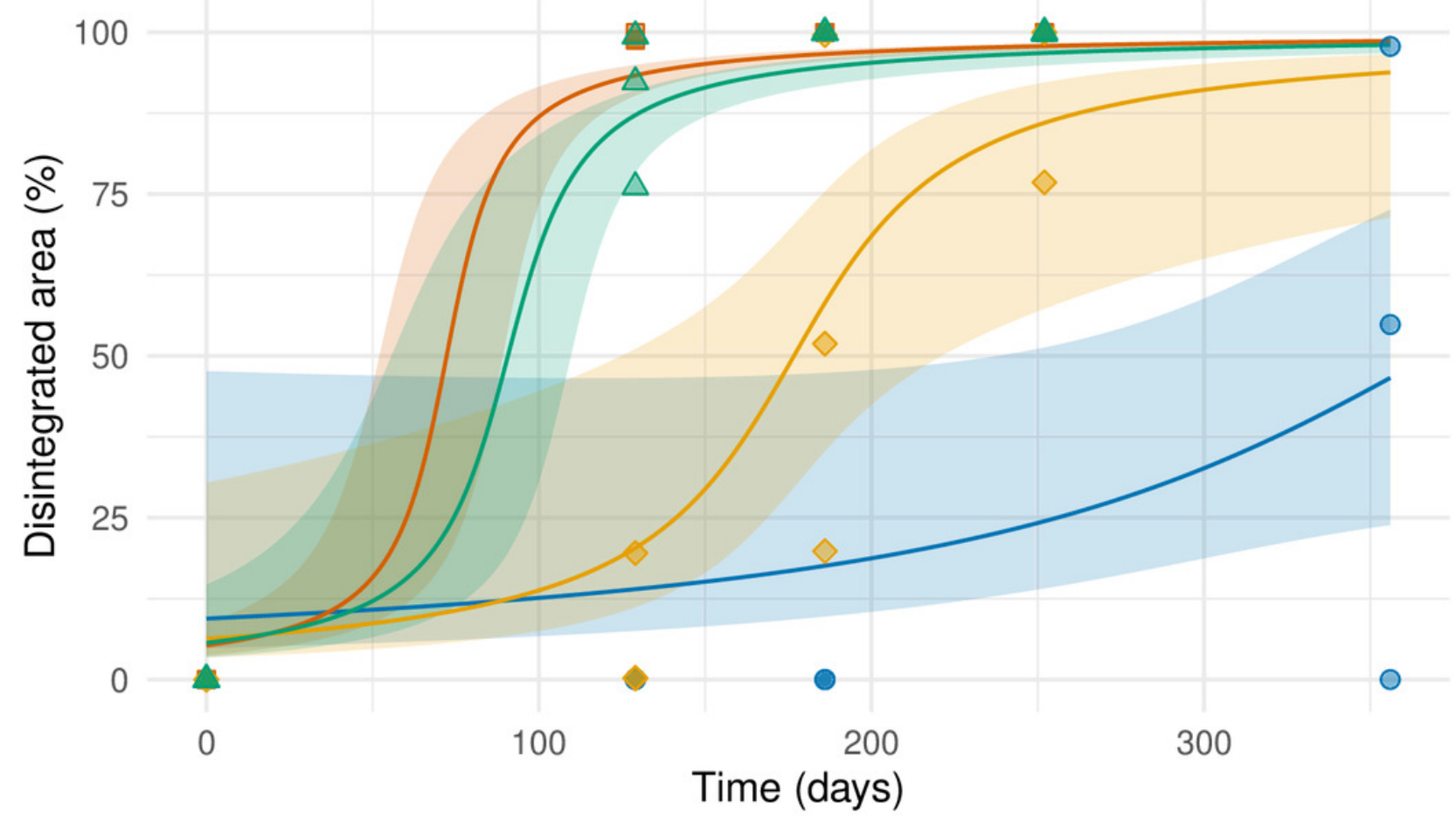

B)

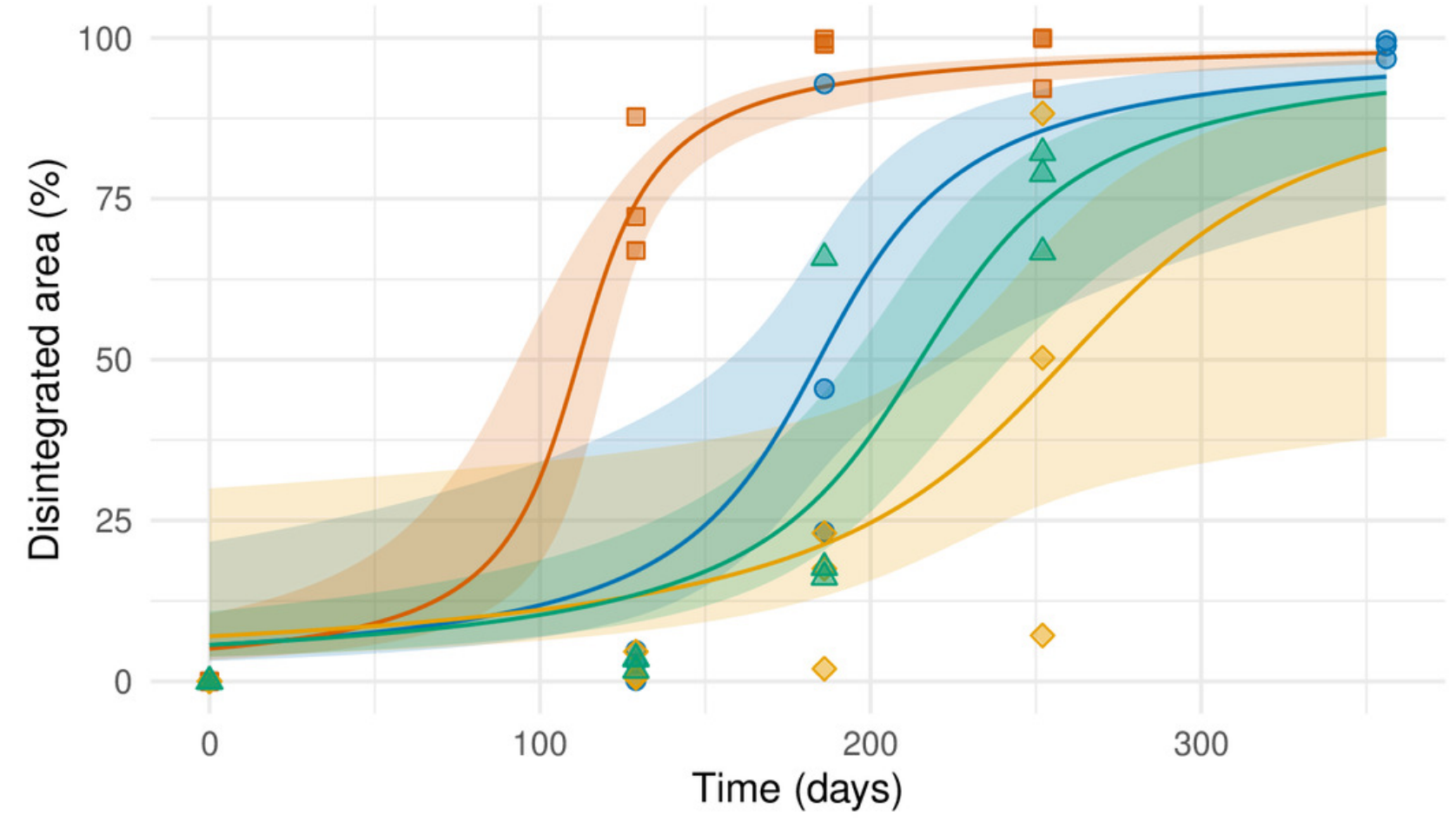

Beach $\neg$ Fetovaia $\because$ Marina di Campo $\triangleleft$ Naregno $\smile$ Portoferraio 
Figure 6
A) Predicted half-life of Mater-Bi HF03V film (12 $\mu \mathrm{m})$ and B) of PHB (85 $\mu \mathrm{m})$ on sediments from different beaches.

The distributions of the $95 \%$ confidence intervals of 500,000 calculated half-life values are shown as violin plots. Significantly different half-life values (empirical $p$-values) have different letters above the plots. The number below the point is the predicted half-life. 
A)

\section{Mater-Bi HF03V}

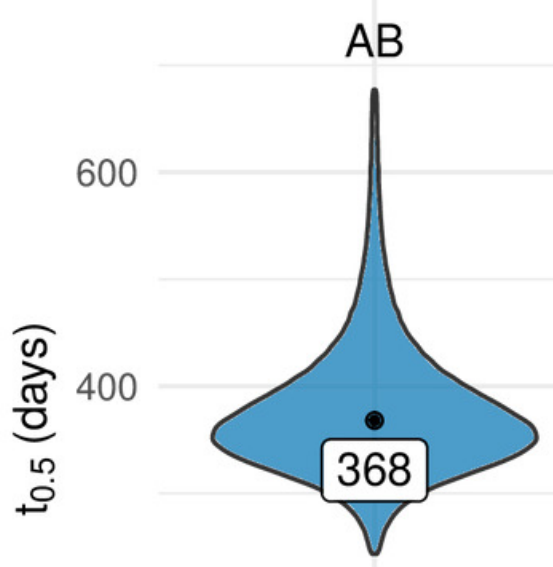

200

0
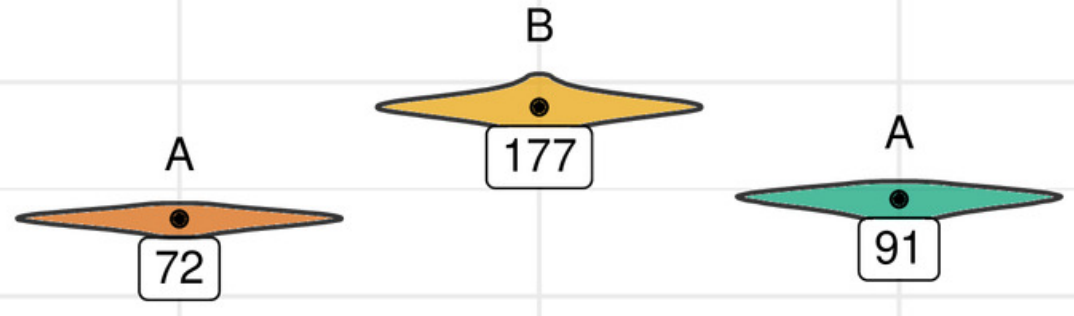

Fetovaia

Beach

B)

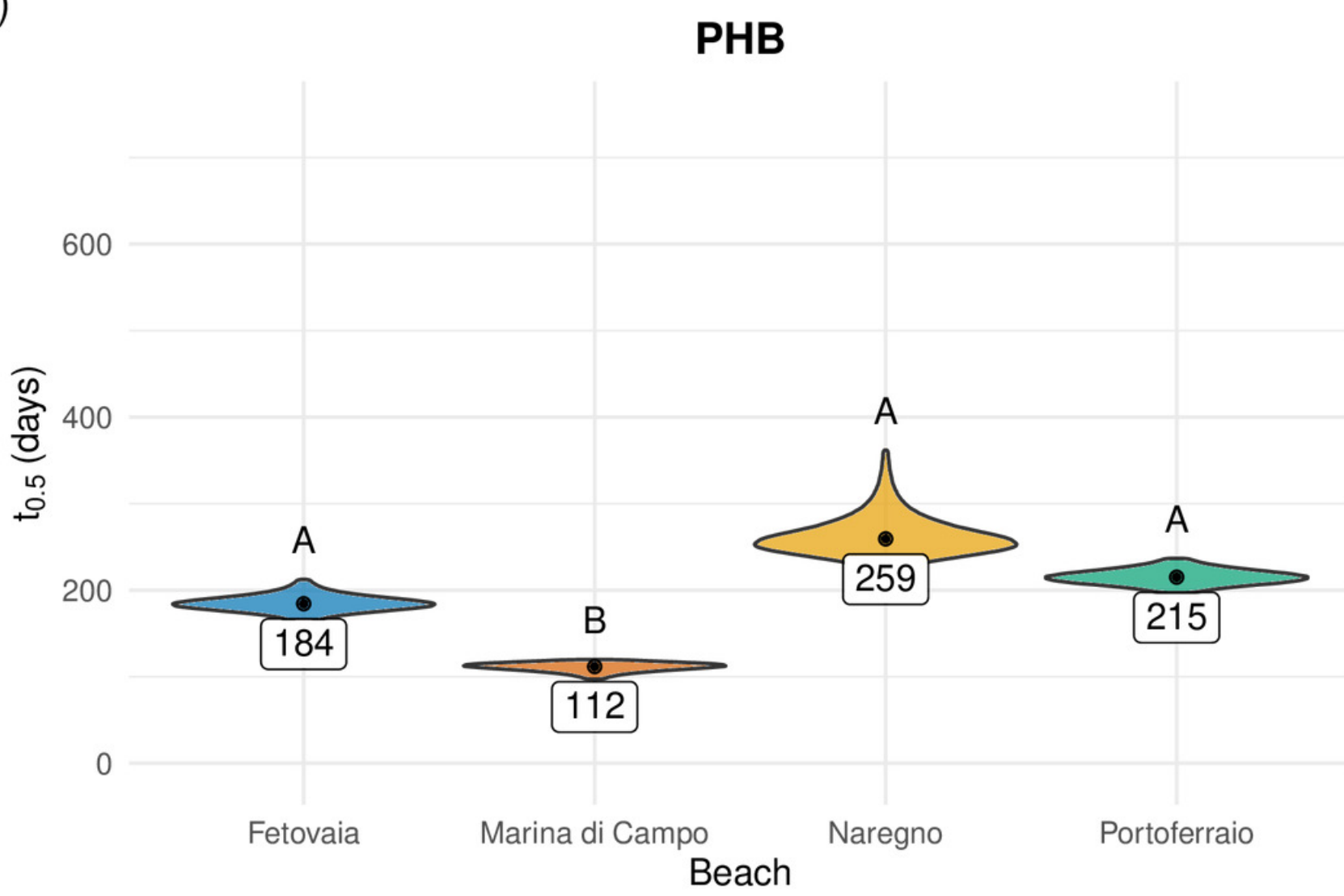


Figure 7

Grain size distribution of sediment from different beaches.

The weight percentage ( $y$-axis) of each size fraction ( $x$-axis) is shown for sediment from different beaches (colour-coded).

\section{Grain size distribution}

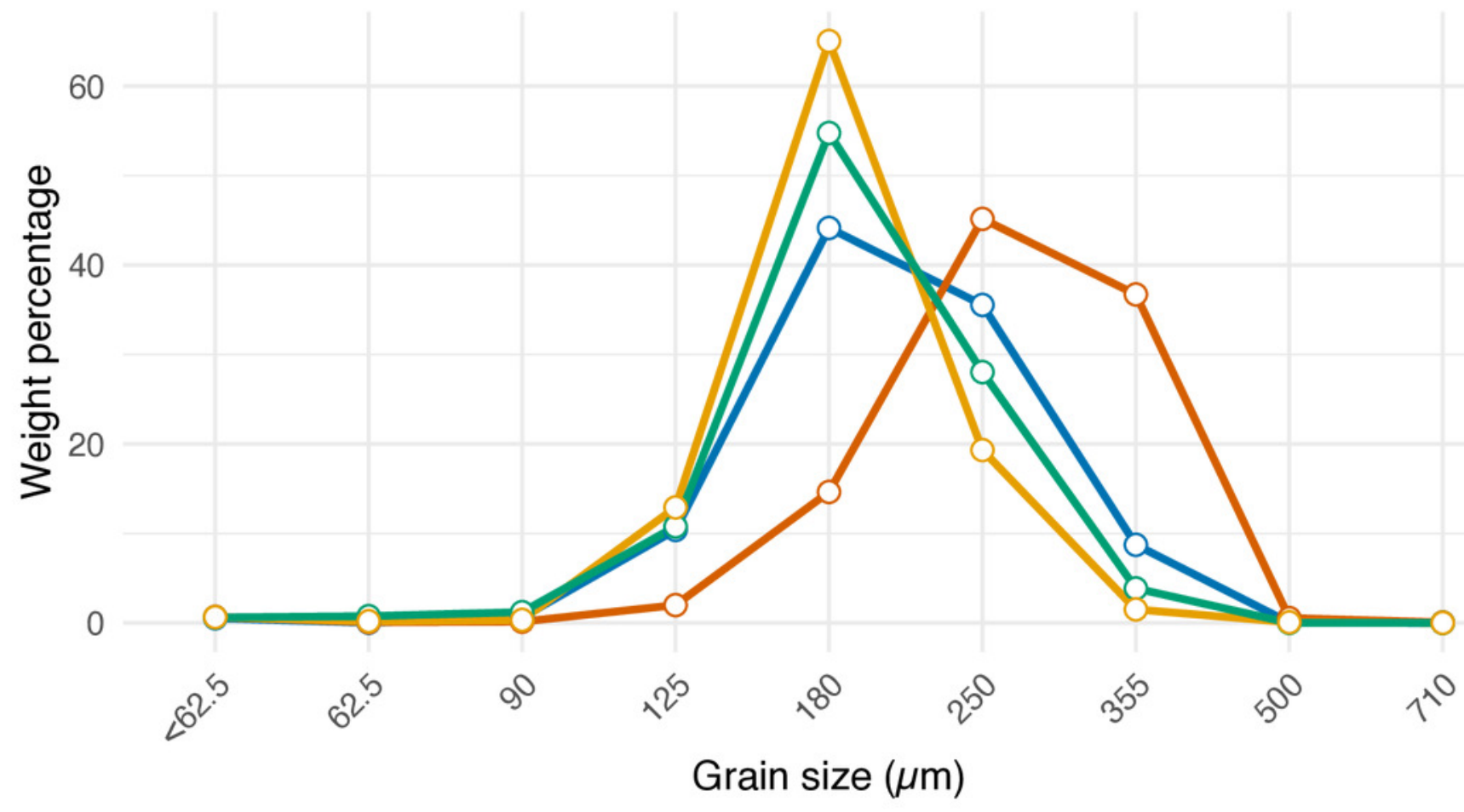

Beach $\mathrm{O}-$ Fetovaia $\mathrm{N}-\mathrm{O}$ Marina di Campo $=\mathrm{O}=$ Naregno $\mathrm{O}-\mathrm{O}$ - Portoferraio 


\section{Table 1 (on next page)}

Table 1: Materials used in both experiments. 


\begin{tabular}{|l|l|l|l|}
\hline Material name & Experiment & Thickness ( $\boldsymbol{\mu m})$ & Sample size (cm) \\
\hline Mater-Bi HF03V & Pilot & 25 & $20 \times 2$ \\
\hline Mater-Bi HF03V & Follow-up & 12 & $6 \times 8$ \\
\hline Polyhydroxybutyrate MIREL P5001 & Follow-up & 85 & $6 \times 8$ \\
\hline HD-PE & Follow-up & 10 & $6 \times 8$ \\
\hline
\end{tabular}

1 


\section{Table 2 (on next page)}

Table 2: Results of sediment analysis.

One sample per sediment type was analysed. LOI = loss in ignition, $\mathrm{ROI}=$ residue on ignition, $\mathrm{DM}=$ dry matter, $\mathrm{TC}=$ total carbon, $\mathrm{TOC}=$ total organic carbon . 


\begin{tabular}{|c|c|c|c|c|c|}
\hline Parameter & Unit & Fetovaia & $\begin{array}{c}\text { Marina di } \\
\text { Campo }\end{array}$ & Portoferraio & Naregno \\
\hline Dry matter & $\%$ & 74.3 & 72 & 74.6 & 75.2 \\
\hline LOI $550^{\circ} \mathrm{C}$ & $\% \mathrm{DM}$ & 1.0 & 0.6 & 1.1 & 1.1 \\
\hline $\mathrm{ROI} 800^{\circ} \mathrm{C}$ & $\% \mathrm{DM}$ & 98.6 & 98.9 & 98.1 & 98.4 \\
\hline Nitrogen (Total-N) & $\mathrm{mg} \mathrm{kg}^{-1} \mathrm{DM}$ & $<200$ & $<200$ & $<200$ & $<200$ \\
\hline Phosphorous & $\mathrm{mg} \mathrm{kg}^{-1} \mathrm{DM}$ & 110 & 110 & 190 & 80 \\
\hline TC & $\% \mathrm{DM}$ & 0.14 & $<0.1$ & 0.18 & 0.11 \\
\hline TOC & $\% \mathrm{DM}$ & $<0.1$ & $<0.1$ & $<0.1$ & $<0.1$ \\
\hline Organic matter & $\% \mathrm{DM}$ & 1.0 & 0.6 & 1.1 & 1.1 \\
\hline Calcium carbonate & $\% \mathrm{DM}$ & 0.9 & 1.1 & 1.8 & 1.1 \\
\hline Silicate & $\% \mathrm{DM}$ & 98.1 & 98.3 & 97.1 & 97.8 \\
\hline Mean grain size & $\mu \mathrm{m}$ & 245.2 & 322.9 & 232.1 & 220.5 \\
\hline Mean grain size & description & fine sand & medium sand & fine sand & fine sand \\
\hline Sorting & & 1.355 & 1.333 & 1.312 & 1.264 \\
\hline Sorting & description & well sorted & well sorted & well sorted & very well sorted \\
\hline Skewness & & 0.072 & -0.062 & 0.071 & 0.077 \\
\hline Skewness & description & symmetrical & symmetrical & symmetrical & symmetrical \\
\hline
\end{tabular}

